\title{
WAHOSAN BUJANG GENJONG: NASKAH KUNO TASAWUF DARI BUMI CIREBON
}

\author{
Muhamad Mukhtar Zaedin \\ Rumah Budaya Pasambangan Jati (mukhtar.rn@yahoo.com)
}

\begin{abstract}
The paper discusses one ancient manuscript stored by the Rumah Budaya Pasambangan Jati; Wahosan Bujang Genjong. Manuscript in the form of the tembang macapat tells about the figure of Bujang Genjong and Rara Gonjeng who in love. The requirement of "understanding of true knowledge" to apply for the young woman to propose the girl, in fact bringing him deeper into the nature of Sufism. In this text, Bujang Genjong is very excited to get something make him pride. The textual representation of the adventures of the youth in the pursuit of ilmu manunggal further refers to an image of the risks and responsibilities that must be borne by everyone to achieve his happiness. Culturally, what can be seen from the content of this manuscript is a culture of pre-marriage which, when viewed from the side of the prospective wife, can draw conclusions about the capacity and sincerity of her future husband. And from the prospective husband, forming the ability and fortitude to the ways and stages that must be lived and championed.
\end{abstract}

Keywords: manuscript, tasawwuf, ilmu sejati, unity (kemanunggalan)

\begin{abstract}
Abstrak
Tulisan ini membahas tentang satu naskah kuno yang disimpan oleh rumah budaya Pasambangan Jati; Wahosan Bujang Genjong. Manuskrip yang berbentuk tembang macapat ini bercerita tentang sosok Bujang Genjong dan Rara Gonjeng yang dimabuk asmara. Syarat "memahami ilmu sejati" untuk melamar yang diajukan sang pemudi kepada pemuda, ternyata membawanya semakin tenggelam dalam alam tasawuf. Dalam teks bertembang tengahan tersebut, Bujang Genjong sangat bersemangat untuk mendapatkan sesuatu yang menjadi kesenangan dan kebanggaannya. Penamsilan teks terhadap petualangan sang pemuda dalam pencarian ilmu manunggal lebih menunjukkan kepada gambaran atas resiko dan tanggungjawab yang harus di pikul oleh setiap orang untuk mendapatkan kebahagiaannya. Secara kultural, apa yang bisa dilihat dari kandungan naskah ini adalah budaya pra-pernikahan yang apabila dilihat dari sisi calon isteri, dapat mengambil kesimpulan tentang kapasitas dan kesungguhan dari calon suaminya. Dan dari sisi calon suami, membentuk kesanggupan dan ketabahan terhadap cara dan tahapan yang harus dijalani dan diperjuangkan.
\end{abstract}

Kata Kunci: manuskrip, tasawuf, ilmu sejati, kemanunggalan

\section{A. Pendahuluan}

Cirebon adalah salah satu tempat strategis yang menjadi pertemuan banyak peradaban dunia. Sejumlah budaya dan tradisi yang berasal dari keragaman masa lalu pun dapat berkembang dengan baik di kota tersebut.
Unsur-unsur yang bersifat animistik, dan dinamistik, berkembang jauh sebelum adanya pengaruh India. Setelah banyaknya kedatangan para pelancong asal anak Benua Asia itu, peradaban HinduBuddha pun turut datang dan memengaruhi sendi-sendi kehidupan 
masyarakat. Disusul kemudian pengaruh Islam, yang terus berkembang dan bahkan menjadi keyakinan mayoritas dari penduduk Cirebon saat ini.

Ada banyak hal yang bisa membuat masyarakat Cirebon bisa memahami, menghayati, dan kemudian meyakini ajaran Islam. Selain karena massifnya gerakan dakwah yang dirintis Syekh Quro, Syekh Nurjati, dan Syekh Sunan Maulana Jati, tentu hal lainnya adalah karena ajarannya sangat menarik dan menyentuh kalbu manusia.

Di Cirebon memang banyak sekali ajaran Islam yang secara langsung ataupun tidak langsung "mengena" terhadap sisi terdalam relung-relung kalbu manusia. Dari sekian banyaknya itu, satu di antaranya adalah ajaran Islam yang bercorak sufistik atau tasawuf.

Memang tidak semua aliran tasawuf menenangkan pikiran, karena sebagian darinya terkadang mengandung ajaran-ajaran yang sangat membingungkan. Kondisi itu selanjutnya acapkali membuat perasaan di dalam diri menjadi tidak beraturan karena daya pikirnya terlalu jauh dan bebas. Kasus ajaran Syekh Lemahabang (atau disebut juga sebagai Syekh Siti Jenar) yang terkenal itu merupakan salah satu contohnya. Ajaran yang terlalu "dalam" membuat sisi "terluar" menjadi seakan tidak berarti sehingga membuat banyak orang tenggelam tidak lagi memikirkan hal-hal yang bersifat duniawi. Akhirnya, sang syekh dihukum oleh dewan ulama yang bernama Wali Sanga. ${ }^{1}$ Setelah peristiwa itu, masih terdapat sejumlah insiden yang berkaitan dengan ajaran kemanunggalan jati semacam ini. ${ }^{2}$

Meskipun banyak terjadi peristiwa yang sangat mengerikan terkait ajaran-ajaran yang bersifat mendalam seperti itu, nyatanya penyelaman terhadap unsur-unsur itu masih seringkali dilakukan. Bahkan dalam masa-masa berikutnya di Cirebon. Bukti konkretnya adalah adanya sejumlah naskah kuno di

1 Syekh Siti Jenar sama sekali tidak ketakutan mendengar vonis hukuman yang dijatuhkan para wali kepadanya. Ia malah menanggapinya dengan senyum, seraya berkata, "Baiklah, silakan segera dilaksanakan." Purwadi, Manunggaling Kawula Gusti: Ilmu Tingkat Tinggi untuk Memperoleh Derajat Kasampurnan, (Gelombang Pasang, 2005), hlm. 193.

2 Setelah kematian sang pendalam makrifat, banyak muridnya yang hendak membalaskan dendamnya. Salah satunya adalah Ki Datuk Pardun yang hendak menghancurkan Cirebon sebagai peluapan atas amarahnya. Namun ternyata upaya itu gagal. Lihat lebih lanjut, Bambang Irianto dan Tarka Sutarahardja, Sejarah Cirebon: Naskah Keraton Kacirebonan (Alih Aksara dan Bahasa Teks KCR 04), Muhamad Mukhtar Zaedin dan Panji Darussalam (Eds.), (Yogyakarta: Deepublish, 2013). 
Bumi Grage yang ternyata berisi tentang ajaran-ajaran sufistik yang sangat dalam itu.

Wahosan Bujang Genjong adalah satu di antara sekian naskah yang dimaksud. Naskah model tembang (puisi) macapat ini menceritakan tentang dua sejoli yang saling jatuh cinta; si Pemuda bernama Bujang Genjong dan si Pemudi bernama Lara Gonjeng. Saat Bujang Genjong mengajukan lamaran kepada Lara Gonjeng, Lara Gonjeng menerimanya dengan satu syarat, yaitu Bujang Genjong harus tahu ilmu sejati. ${ }^{3}$ Walaupun belum terlalu mendalam, Dahuri pernah mengungkapkan sebagian isi dari naskah tersebut. Menurutnya, naskah kuno itu bercerita tentang sosok Bujang Genjong dan Rara Gonjeng yang merupakan wujud dari simbolsimbol raga dan jiwa yang keduanya selalu saling merindu. ${ }^{4}$ Dalam konteks ini, merindu yang dimaksud adalah merindu akan kebersamaan dan persatuan untuk dapat menjalankan irodah, atau kehendak yang oleh Al Ghazali dituliskan

Saeful Bahri, Harapandi Dahri, Ahmad Kholid Dawam, Muhamad Rosadi, Syarif, Zulkarnain Yani, dan Muhammad Tarobin, Koleksi dan Katalogisasi: Naskah Klasik Keagamaan Bidang Tasawuf, (Jakarta: Balai Penelitian dan Pengembangan Agama Jakarta, 2013), hlm. 352.

Rokhmin Dahuri, dkk., Budaya Bahari Sebuah Apresiasi di Cirebon, (Jakarta: Perum Percetakan Negara RI, 2004), hlm. 225-226. sebagai dasar nilai spesialnya sebagai makhluk Allah yang paling sempurna. ${ }^{5}$ Tujuan yang sangat indah itu tentunya dapat dicapai apabila ada kebersamaan dan kesatuan yang hakiki.

Tulisan ini berupaya untuk menambahkan ragam cara pandang terkait naskah WGB tersebut, mengingat kandungan isi yang ada di dalamnya belum pernah dituliskan secara khusus oleh siapapun. Karyakarya yang ada masih sebatas menyinggungnya secara sekilas dan terbatas, termasuk dalam tulisantulisan yang pernah diuraikan sebelumnya.

\section{B. Deskripsi Naskah}

Naskah Wahosan Bujang Genjong (WBG) atau disebut pula sebagai Naskah Suluk Bujang Genjong (NSBG) merupakan naskah kuno yang berada di Rumah Budaya Pasambangan Jati, Jalan Gerilyawan No. 04, Kelurahan Drajat, Kecamatan Kesambi, Kota Cirebon. Pada mulanya, naskah ini adalah warisan turun temurun keluarga yang didapatkan oleh Drh. Bambang

5 Terkait hal itu, Al Ghazali berkata, Hati manusia itu terkhusus dengan pengetahuan dan kehendak yang menyebabkannya berbeda dari seluruh hewan. Baca lebih lengkap dalam Abu Hamid Muhammad Al-Ghazali, Ihya 'Ulum alDin, (Beirut: Daar al Fikr, 1989), Juz III, hlm. 17. 
Irianto, BA. Dari leluhurnya. Kemudian dengan seizin pemilik, saya bisa melihat naskah tersebut dan mencoba untuk menyelaminya sehingga bisa meraih isi yang terkandung di dalamnya.

Teks ini memiliki judul Wahosan Bujang Genjong, penamaan itu mungkin karena isinya bercerita tentang sosok utama yang bernama unik, yaitu Bujang Genjong. Naskah tersebut berada dalam kondisi yang baik dan utuh, dan bahkan cover naskah yang berwarna biru itu pun masih ada dengan kondisi yang tidak rusak sama sekali. Tinta yang dipakai adalah tinta hitam dengan bahanbahan yang tradisional. Adapun ukuran dari tiap lembaran naskah ini adalah $21 \mathrm{~cm} \mathrm{x} 16 \mathrm{~cm}$, dan tiap halaman dari lembaran itu memiliki ukuran teks $17 \mathrm{~cm} \mathrm{x} 14 \mathrm{~cm}$ yang tertulis dengan sangat rapi.

Ketebalan dari manuskrip berbau tasawuf ini adalah 36 halaman, di mana di setiap halamannya terdapa 10 baris aksara yang dituliskan oleh pembuat atau penyalinnya. Susunan aksara yang ada di dalam buku tua ini bersifat recto verso (bulak-balik) karena dua sisinya berisi tulisan, sehingga secara keseluruhan terdiri dari18 lembar kertas di luar cover. Naskah ini dibuat dalam kertas bergaris, yang sama sekali tidak terlihat ada iluminasi ataupun cap kertasnya, dan dilindungi oleh cover leces berwarna biru.

Naskah ini tidak memiliki kolofon sehingga sulit diketahui kapan ditulis oleh pengarangnya. Namun meskipun demikian, jika melihat kondisi dan bentuk naskah, maka dapat diduga bahwa tulisan tua tersebut berasal dari masa abad ke19, atau dari sekitar tahun 1800 hingga tahun 1899. Pegon merupakan aksara yang digunakan oleh pengarang dalam menulis naskah ini, dengan model tulisan yang berbentuk puisi.

Naskah ini pernah dicatat dalam katalog naskah tentang tasawuf oleh Balai Penelitian dan Pengembangan Agama Jakarta dengan nomor 10/H12NA(16)/Tw1/TA/2012.

\section{Tinjauan Umum Naskah}

Melihat dan membaca WBG dengan cermat, ternyata mampu membuka cakrawala pengetahuan yang sangat luas tentang ajaranajaran tasawuf dalam Islam. Naskah yang diwakili oleh dua sosok sentral bernama Bujang Genjong dan Rara Gonjeng ini memberi gambaran yang manis serta makna yang dalam tentang konsepsi persatuan diri. Keduanya seakan menjadi simbol 
dan peribaratan kemanunggalan yang nyata, bukan sekedar kisah tentang muda-mudi yang tengah dimabuk cinta semata.

$$
\text { Dalam naskah ini, }
$$
penyampaian alur ceritanya cukup sederhana sehingga lebih mudah untuk dipahami oleh khalayak luas. Namun, uraian itu bukan hanya tentang cerita fiksi ataupun kisah yang dibumbui romantisme dan unsur-unsur tragis, melainkan metode cerdas yang digunakan oleh pengarang untuk menyampaikan pesan-pesan kepada para pembacanya. Tulisan WBG ini mencatatnya sebagai metode pewayangan, wayang amot wawayangan, atau penggambaran yang menjadi cara teraman di masa itu untuk menjelaskan ataupun menjabarkan hal-hal yang amat rumit dan sulit, yang biasanya terkandung di dalam runtutan kata-kata yang tersusun dengan rapi dan teralun dengan indah.

Secara definitif, nama dari tokoh-tokoh yang tercantum dalam naskah ini pun memiliki arti tersendiri karena diciptakan dengan tujuan tertentu. Apabila dilihat dari sisi harfiah, nama Bujang Genjong dan Bujang Lamong pun ternyata memiliki kedekatan dengan istilah "Bujangga", yang memang seringkali disebutkan dalam tembang-tembang macapat. Betul sekali apabila Dahuri memiliki dugaan yang kuat akan adanya maksud-maksud tertentu di dalam rangkaian cerita yang ditulis oleh pengarang naskah.

Dalam kesimpulannya, ia memberi cetakan tebal pada makna ilmu manunggal yang diartikannya sebagai kemanunggalan antara kawula dengan gusti, bisa meloncat naik ke arah manunggaling ilmu antara syari'at, tarekat, hakikat, dan makrifat dalam diri orang Cirebon, dengan kalimat lebih jelas bahkan dikatakan sebagai persiapan manusia agar dapat membekali diri dengan empat ilmu (syari'at, tarekat, hakikat, dan makrifat) dalam bertindak, bergaul, berfikir dan beribadah. $^{6}$

Saat Cirebon mengalami masa keemasaannya, ajaran tasawuf merupakan ajaran agama Islam yang paling dapat diterima oleh khalayak luas masyarakat. Islam model inilah yang diterima dan disukai oleh masyarakat Cirebon pada saat itu. Hanya saja, seiring dengan perjalanan waktu, pemikiranpemikiran baru bermunculan sesuai dengan aliran atau madzhab masingmasing pendatang, dan bahkan berubah dengan adanya pelbagai

\footnotetext{
6 Rokhmin Dahuri, dkk., Budaya Bahari ...., hlm. 26.
} 
benturan pemikiran. Satu dari sekian benturan itu, yang paling populer adalah benturan pemahaman yang terjadi antara Dewan Wali Sanga dengan Syekh Siti Jenar. Benturan antara Syekh Siti Jenar dan Dewan Wali Sanga tidak selesai hingga eksekusi terjadi terhadapnya, dan ketika suatu paham sudah berkembang dalam masyarakat, maka ada penerus yang menggantikannya hingga saat ini. Mungkin hal inilah yang menjadi salah satu sebab terhadap kalimat tunggal di sebagian naskah Cirebon, WBG termasuk didalamnya, tidak diarahkan kepada manunggal antara gusti dan kawula.

Dalam perspektif sastra, WBG masuk ke dalam kategori karya sastra yang diwujudkan dalam bentuk Tembang Macapat. ${ }^{7}$ Adapun tembang yang ada di naskah ini terbagi menjadi sejumlah kelompok

Tembang Macapat merupakan bagian dari bentuk kesusasteraan yang di tanah Jawa, termasuk di antaranya ada juga di Cirebon. Seorang budayawan Cirebon, Kartani, memberi penjelasan bahwa macapat berarti membaca empat-empat, maca papat-papat. Membaca secara empat wanda empat wanda dalam tembang ini sebenarnya sangat sulit dipahami oleh generasi muda sekarang, karena mereka tidak mendapatkan gambaran dalam pemikiran mereka bentuk tehnis membaca empat-empat. Bagi kami, mereka tidak salah sama sekali, karena tidak ada orang yang memberinya pelajaran tentang itu. Tentang Macapat, lihat Yatna Supriatna, Sastra Klasik Cerbon, (Cirebon: Dinas Kebudayaan dan Pariwisata Kota Cirebon, 2008), hlm. 6-7. layaknya naskah-naskah tembang lainnya, yaitu: kasmaran, megatruh, pangkur, durma, dan khinanthi; dan diakhir naskah ini ditutup dengan tembang kasmaran. Lazimnya, tembang-tembang ini dimasukkan ke dalam jenis tembang tengahan ${ }^{8}$ karena karakter bahasa yang muncul dan mewarnai WBG tidak dapat dikategorikan sebagai jenis dari tembang kawi, yang umumnya ada di dalam khazanah kesustraan Jawa Tengah ala Mataram. Penggunaan dan pemilihan bahasa yang semacam inilah yang secara tidak langsung menunjukkan bahwa WBG sangat eksklusif sebagai suluk pesisiran Cirebon dan merupakan tembang yang masyhur karena memiliki akar yang khas pada zamannya.

Memang semua naskah di wilayah Cirebon yang memiliki isi yang sama ini belum ditelaah secara keseluruhan, akan tetapi melalui satu naskah ini, kita dapat menangkap ide, gagasan, gambaran prilaku, dan ajaran luhur yang merupakan potret budaya Cirebon yang berkembang pesat pada saat itu. Penekanan

\footnotetext{
8 Tembang tengahan, konon merupakan hasil dari karyanya Resi Wiratmaka yang menjadi seorang pandita istana Janggala dan disempurnakan oleh Pangeran Panji Inokartapati dan saudaranya. Liha juga Ben Arps, Tembang in Two Traditions: Performance and Interpretation of Javanese Literature, (London: School of Oriental and African Studies, 1992), hl. 17.
} 
pengajaran suluk (tasawuf dalam bentuk tembang) yang bertitik berat pada penamsilan yang begitu nyata mendominasi naskah ini. Dengan kata lain, penggunaan bahasa ibarat seperti lir, lirpenda, lirkadiya dan terkadang figuratif, sangat menyentuh hati dan membuat kita terhanyut di hempasan ombak sastranya. Oleh karena itu, apabila kita membaca WBG secara polos tanpa adanya terjemahan dan tafsiran, maka sebetulnya kita dapat menikmati alunan kata demi kata yang tersusun dalam WBG secara puitis, bahkan jika kita mau lebih terbuka, 'dominasi bahasa pengibaratan' yang dipakai oleh pengarang dalam menulis WBG sanggup menuntun kita ke dalam kesadaran berbahasa yang halus dan indah.

Hal itu dimaksudkan oleh penulisnya, agar kalimat dan makna yang terkandung dalam suluk Cirebon ini memiliki nuansa spiritual dan tasawuf yang kuat. Namun memang perlu digaris bawahi pula bahwa semua prilaku yang digambarkan oleh WBG tak lepas daripada Cirebon sebagai ruang gerak penulisnya. Di samping itu, keterbatasan referensi yang ada atau kurangnya pengetahuan penulis WBG terhadap al-Quran dan Hadits terasa sekali. Namun demikian, semangat 'bersuluk' tampaknya cukup kuat di kalangan Islam Cirebon pada saat itu, sehingga WBG - terlepas dari kekurangan dan kelebihannya - menjadi naskah suluk yang khas ala Cirebon. Gagasan dan pemikiran yang tertuang dalam naskah tersebut sudah dianggap cukup kuat dan dapat menjelaskan konsep wahdatul wujud yang tumbuh dalam pemikiran tasawuf Timur Tengah menjadi manunggal ala Cirebon yang bisa dipahami berbeda dengan konsep dengan manunggal versi asalnya atau bahkan versi Siti Jenar. Manunggal versi Siti Jenar memang merupakan salinan dari daerah asalnya dengan kertas (bahasa) Jawa yang pada saat itu masyarakatnya masih kuat oleh pengaruh-pengaruh Hindu dalam peristilahan ajaran prinsip ketuhanan. Sehingga muncul anggapan bahwa Islam dan Hindu-Budha sebenarnya sama dalam memandang Tuhannya. WBG memilih jalan yang tergolong sederhana dan dapat dicerna oleh kalangan umum, sehingga kebingungan orang tentang persamaan Islam dan Hindu dalam memandang Tuhannya, dalam konsep menunggal, tak terjadi dalam pengajaran naskah tersebut.

Pengajaran dengan model suluk yang digunakan oleh WBG bukan tanpa awal dan permulaan. Di Timur Tengah sendiri, suluk diajarkan dengan tembang atau 
nadhom-nadhom yang ternyata mendapat respon yang cukup baik dikalangan masyarakat Islam. Ide-ide yang kadang sulit diungkapkan dengan uraian model nastar atau prosa begitu mudah dan lancar di gubah dalam tembang dan nadhom. Sehingga kesalah pahaman antara kelompok (kaum) yang pro wahdatul wujud dan kontra wahdatul wujud dapat dihindari.

Dalam konteks memahami kaum wujudiyyah (orang-orang yang memahami tentang wahdatul wujud) sendiri, al-Banjari memberikan dua kategorisasi kelompok, yaitu: wujudiyyah

mulhid dan wujudiyyah muwahhid. Wujudiyyah mulhid termasuk golongan yang sesat lagi zindiq. Wujudiyyah muwahhid, menurut dia, "yaitu segala ahli sufi yang sebenarnya", mereka dinamakan kaum wujudiyyah "karena bicaranya dan perkataannya dan i'tikadnya itu pada wujud Allah". Ia tidak menjelaskan isi ajaran mereka, tetapi sebagai lawan dari wujudiyyah mulhid tadi, wujudiyyah muwahhid tentu tidak menganggap bahwa Allah tidak "tiada maujud melainkan di dalam kandungan wujud segala makhluk", atau "bahwa Allah itu ketahuan zat (esensi)-Nya nyata kaifiat-Nya daipada pihak ada. Ia maujud pada kharij dan pada zaman dan makan", dan tidak pula membenarkan pernyataanpernyataan seumpama "tiada wujudku, hanya wujud Allah", dan sebagainya, yang mencerminkan pandangan wujudiyyah mulhid itu. Keterangan al-Banjari mengenai ajaran kaum wujudiyyah mulhid itu kelihatan sangat mirip dengan keterangan ar-Raniri, yang dalam abad sebelumnya menyanggah penganut-penganut terkait di Aceh. Begitupun yang dipandang oleh al Palimbani. ${ }^{9}$

Dengan dasar uraian tersebut, pada dasarnya konsep tersebut tidak jauh berbeda dengan ajaran wahdah al-wujud Ibnu Arabi. Ajaran ini juga memandang alam semesta ini sebagai penampakan lahir Allah dalam arti bahwa wujud yang hakiki hanya Allah saja-alam semesta ini hanya bayangan-bayang-Nya. Dari satu segi, ajaran ini kelihatan sama dengan ajaran tauhid tingkat tertinggi. Kedua ajaran itu memandang bahwa wujud yang hakiki hanya satu-Allah, tetapi dari lain segi wujudiyyah muwahhiddan wihdah al-wujud ini tidak sama dengan pandangan "bahwa yang ada hanya Allah" dalam ajaran yang terakhir ini hanya tercapai dalam keadaan yang disebut fana, yakni

9 Amsal Bakhtiar, Tasawuf dan Gerakan Tarekat, (Bandung: Angkasa, 2003), hlm. 70. 
terhapunya kesadaran akan wujud yang lain, sedang dalam ajaran wihdah al-wujud, pandangan tersebut kelihatan sebagai hasil penafsiran atas fenomena alam yang serba majemuk ini. Di samping itu, pandangan tauhid tingkat tertinggi itu, nampaknya didasarkan atas asumsi bahwa esensi Allah yang mutlak itu dapat dikenali secara langsung, tanpa melalui penampakan lahir-Nya, asumsi ini dibantah oleh Ibnu 'Arabi, karena menurut dia Allah hanya bisa dikenal melalui nama-nama dan sifat-sifat-Nya. ${ }^{10}$

Jika kita hendak membanding WBG dengan syair-syair suluk yang telah ditulis oleh Hamzah Fanshuri, maka tek pelak keduanya mempunyai semangat yang sama dalam hal mengusung wahdatul wujud atau manunggal. Paham tersebut menjadi sangat trend dan dianggap sebagai paham yang tinggi dalam ajaran suluk pada masanya. Walaupun kita juga tahu, pada saat yang sama, ada sekelompok yang menentang paham itu, bahkan dengan menggunakan kekuasaan sebagai alatnya. Sehingga kedua aliran (pro dan kontra wahdatul wujud) saling berebut kesempatan

10 Pusat Penelitian dan Pengembangan Lektur Agama (Indonesia), Naskah Klasik Keagamaan Nusantara: Cerminan Budaya Bangsa, Vol. I, (Jakarta: Departemen Agama RI, Badan Litbang Agama dan Diklat Keagamaan, Puslitbang Lektur Keagamaan, 2005), hlm. 49-50. untuk mendapatkan tempat dihati para penguasa. Namun demikian, keduanya (WBG dan Syair Hamzah Fanshuri) mempunyai perbedaan yang cukup mendasar dari segi metode pengajarannya. Naskah tua dengan basis bahasa dan ruang Cirebon yang menjadi latar belakangnya, menjadi tampak lebih samar dengan paham yang dibawanya. WBG menamsilkan pahamnya dengan menekankan kesamaan antara Jawa dan Sunda, atau dengan kata lain, manuskrip tersebut menegaskan bahwa Jawa (bahasa Jawa Cirebon) dan Sunda sebenarnya satu dalam hidup, tujuan, dan mati. WBG ingin mengatakan bahwa perbedaan Jawa dan Sunda terletak hanya sebatas bahasanya saja, tetapi makna yang dikehendaki dari ucapan yang berbeda itu sebenarnya sama. Untuk itulah, perbedaan bahasa sebenarnya bukan sesuatu yang dapat menjadi hilangnya makna yang sama, yang dikehendaki oleh bahasa yang lain. Jadi, masing-masing bahasa punya kata tersendiri yang dapat menjelaskan makna yang dimaksud oleh bahasa yang lain. Dengan cara beginilah WBG menjelaskan pahamnya tentang tunggal dan siji atau wahdatul wujud. Atau dengan kata lain, kedua bahasa yang berbeda itu sebenarnya punya maksud yang sama, dan tentunya secara lumrah 
masing-masing bahasa, apabila digunakan, menuju kepada 'satu makna' yang dikehendakinya, walaupun didalam kamusnya, kata itu memiliki beberapa dan bahkan puluhan arti.

Pengibaratan mumpuni dan kalimat tamsil cerdas yang tersurat dalam WBG, menunjukkan dengan jelas bahwa pengarangnya bukanlah orang biasa ataupun rakyat kebanyakan. Kemampuannya itu benar-benar menunjukkan bahwa pengarang adalah Bujangga yang profesional, terampil dan mampu membawa imajinasi pembaca kepada alur pemikiran yang dikehendakinya. Menurut kaidah ilmu sastra, kebesaran seseorang dapat dilihat dari bahasa yang digunakannya. Dengan kata lain, kebijakan bahasa yang dipakai dalam penulisan suatu karya, dapat menjadi tolok ukur bagi penulisnya. Kalimat tamsil yang semacam inilah yang mewarnai isi kitab-kitab Ibnu Arabi, al-Ghazali, Ibnu Athoilah, dan lain-lain sewaktu mereka menjelaskan tentang ilmu mukasyafah, ilmu makrifat, dan hulul yang dianutnya. Hanya saja perbedaan selalu ada diantara sesamanya dalam sebagian masalah yang diutarakan. Namun secara garis besar, metode yang digunakan dalam hal menghadapi kesulitan saat menjelaskan tunggal, kasyaf, atau nyata kepada pembaca, mereka menempuh jalan yang sama. Mereka beranggapan, bahwa ma'rifatul haq sesuatu yang pelik, sehingga sulit untuk dijelaskan dan ditulis dengan kalimat lepas diatas lembaran kertas. Karena didorong oleh rasa ingin berbagi ilmu yang mulia kepada pembaca atau tepatnya murid, penamsilan itu dilakukan oleh mereka, agar pembaca menangkap setetes maksud dari ma'rifatul haq yang diurai dengan tamsil. Untuk bisa merasakan atau menyaksikan secara langsung, maka pembaca atau atau yang disebut dengan istilah murid harus dapat melakukan apa yang telah dikerjakan oleh orang yang mencapai maqom ma'rifat atau maqom kasyaf secara penuh dan konsisten. Maqom ini adalah maqom yang tertinggi dalam ilmu suluk yang berkembang di dunia Islam dibelahan dunia manapun. Akan tetapi, Kartani (2004), menambahkan satu tingkat lagi di atas ma'rifat dengan tingkatan ma'lum atau maklum. Artinya: tingkatan maklum adalah kondisi pemikiran dan kesadaran seseorang tidak lagi fana fil kull (sirna dalam keseluruhan) tertuju hanya kepada Allah SWT. semata, tetapi sudah bisa membagi kesadarannya kepada Allah SWT. dan makhluk-Nya. Jadi, fana yang dipakai oleh orang yang mencapai maklum adalah fana fil ab'adl (sirna di dalam 
kesebagianan), yaitu seseorang di samping tenggelam dalam musyahadah fillah, dia juga mampu berkomunikasi dengan orang lain secara benar dan lancar. Ketenggalaman dalam dunia semacam ini meskipun membingungkan, tetap menjadi hal yang diperhatikan. ${ }^{11}$

Dalam kesustraan Cirebon dan Nusantara, sebenarnya ada banyak suluk-suluk yang mirip dengan WBG, terutama yang berasal dari Aceh, dan kita, khusus Cirebon, dapat mendengarkannya dalam pagelaran Macapat yang sering dilaksanakan oleh kalangan tua Cirebon. Hanya sayangnya adalah kurangnya minat kalangan muda terhadap jenis pagelaran kesenian yang satu ini. Mungkin karena pagelaran macapat di Cirebon tergolong sakral, atau bahasa yang dipakai dalam tembang ini tak dapat dimengerti kebanyakan kalangan mudanya.

\section{Menurut hemat kami,} kesakralan yang ada dalam pagelaran macapat tak perlu menjadi alasan untuk lari dari kesenian yang unik

11 Meski telah banyak ditelisik dengan ragam sudut pandang, nyatanya yang selalu berhubungan dengan agama, selalu menjadi tema penelitian yang senantiasa segar dan favorit bagi banyak pihak. Tendi, "Islam dan Agama Lokal dalam Arus Perubahan Sosial", At-Tahrir, Vol. 16, No. 1 (2016), hlm. 48-49. dan menarik ini. Mereka harus coba berusaha mengerti dan masuk di dalamnya agar dapat memberikan perubahan metode pagelaran yang semula sakral menjadi meriah. Anggaplah tembang macapat adalah suatu puisi klasik yang dapat dibaca secara moderen, sebagaimana puisipuisi yang lain. Memang harus diakui, antara tembang dan puisi sangat berbeda dalam segalanya. Dari segi pembacaan khususnya tembang macapat memang mempunyai aturan yang sangat ketat. Memang idealnya, tembang macapat harus dilantunkan sebagaimana mestinya, karena tembang adalah alunan lagu yang memerlukan kemerduan suara disamping mengerti teknik-teknik pelafalannya. Sementara puisi penekanannya pada inotasi suara yang tidak memerlukan teknik lagu secara khusus. Namun memang ke duanya mempunyai kesamaan dalam kemerduan dan ketegasan suara. Karena itulah, harus dicapai jalan keluar yang dapat menjawab problem yang berkaitan dengan pakem tembang agar bisa dengan segala kepantasannya diperlakukan sebagaimana puisi modern.

Pagelaran macapat di Cirebon cenderung mengarah ke arah ritual yang sakral. Hal itu karena memang, secara keseluruhan, macapat Cirebon berisi babad, cerita rakyat, dongeng, 
dan sedikit sejarah dan ajaran sufi (suluk). Di dalam kisah yang disebutkan dalam tembang macapat ada sederetan nama tokoh Cirebon zaman dahulu seperti; Ki Gede, Ki Buyut, Ki Ageng, Ki Wira, dan Tokoh Panutan sentral seperti; Sunan Gunung Jati, Mbah Kuwu Sangkan dan para wali yang lain yang telah berjasa terhadap masyarakat Cirebon dalam banyak hal, terutama kesejahteraan batin dan jiwa. Berangkat dari tradisi tahlilan dan penghormatan terhadap orang yang telah meninggal, tak dapat diekspresikan secara pantas selain mengadakan doa dan kirim surat alFatihah untuk mereka, maka para Bujangga Cirebon yang hendak mengadakan tembang macapat, merasa sungkan menyebut-nyebut nama Sunan Gunung Jati atau para Ki Gede dengan tanpa mengirim surat al Fatihah dan doa-doa kepada mereka terlebih dahulu. Dari sinilah berawalnya tradisi pembacaan doa arwah kepada sesepuh dalam pagelaran tembang macapat Cirebon. Sehingga pagelaran tembang macapat Cirebon seperti dikhususkan untuk kalangan orang tua, sebagaimana tahlilan yang hanya dipimpin dan dilakukan oleh masyarakat yang memang kebanyakan orang tua. Jadi di mata anak Cirebon yang kurang peduli dengan pagelaran macapat, menyaksikan pagelaran ini, dalam pemahaman mereka, sama dengan menyaksikan tahlilan. Pembacaan doa arwah di awal prosesi macapat yang merupakan tiruan ritual tahlil yang digunakan untuk mendoakan orang yang sudah meninggal dianggap oleh mereka seperti tak ada perbedaan antara pagelaran macapat dan tahlilan. Jadi kesakralan macapat dengan kemenyan dan doa arwah sebenarnya adalah tradisi yang dapat digantikan dengan model lain yang lebih digandrungi oleh kalangan muda masa kini. Dan bagi kami, tegaknya suatu seni adi luhung tentunya lebih penting daripada mempertahankan modenya dengan sedikit orang yang tertarik dan mengambil manfaat dari padanya. Meniadakan acara kirim arwah dan doanya beserta bakar kemenyan saat pembukaan prosesi pagelaran tembang macapat, dan digantikan dengan yang lain atau tanpa penggantinya, tetap masih memelihara kelestarian macapat, dan mungkin juga menjadi salah satu cara untuk membawa macapat ke lingkaran anak muda.

\section{Pembacaan dan Kajian Atas WBG}

Pada umumnya, pembacaan atas WBG akan dimulai dengan cerita perilaku dan tradisi kehidupan masyarakat Cirebon yang gemar membicarakan orang lain di saat 
malam mulai turun. Hal itu tidak jauh berbeda dengan halnya naskahnaskah lain yang berbentuk macapat yang berisi babad, dan dongeng, yang umumnya berkisah tentang cerita seperti itu. Cerita atau informasi tentang potret kehidupan di Cirebon pada masa lampau ini agak detail dan tak ditutup-tutupi. Idealisasi yang dipegang teguh oleh Bujang Genjong saat hendak menikah adalah dia tidak akan menikah sebelum mempunyai pekerjaan yang mencukupi. Padahal disisi lain dia menjadi idola para gadis dan janda kembang di seantero desa, dan Rara Gonjeng merupakan kenalannya yang peling dekat di banding yang lain. Tetapi sebenarnya bukan masalah idealisme masyarakat secara umum, hanya dia hendak, juga karena menjadi persyaratan dari Rara Gonjeng sendiri, mencari ilmu dan ngelmu yang dapat menerangi hatinya sepanjang masa. Hal ini tersurat dan tersirat dalam bait "pangaweruhe kinaweruhan". Sangat mengejutkan! Di satu sisi, pelajaran yang ada dalam WBG mengutamakan pendidikan yang dapat menjadi penuntun kehidupannya dari dunia hingga akhirat, yang tentunya dapat menghabiskan usia remaja. Di sisi lain, kita tahu bahwa zaman dahulu (zaman kakek dan nenek kita) banyak yang menikah di usia remaja.
Atau mungkin mereka menggunakan sistem kawin gantung $^{12}$ yang terkenal dan dapat menjadi solusi dalam kerumitan ini. Dan tampaknya kemungkinan yang ketiga menjadi jalan tengah yang ditempuh oleh sebagian orang kaya di berbagai daerah Cirebon saat itu. Kita sering mendengar cerita masa lalu, saat kakek dan nenek kita masih muda, yang menyebutkan bahwa seringkali setelah usai pernikahan, dalam jangka satu minggu atau empat puluh hari, pengantin lelaki berangkat kembali ke pesantren, karena pada saat itu belum ada sekolah, untuk meneruskan pelajarannya yang belum tamat. Hal itu berjalan hingga dua, tiga tahun atau bahkan lebih lama, tergantung dari kecepatan dan kecerdasan yang dimiliki olehnya sehubungan dengan kesulitan dan tingkatan pelajaran yang sedang ditempuhnya.

Sekilas, naskah ini seakan sebuah suluk yang memang secara bahasa dan isinya itu benar-benar suluk luar dan dalam. Akan tetapi, fakta yang ada, mendorong kita

\footnotetext{
12 Adat yang demikian ini masih ada di Cirebon dengan nama yang sedikit berbeda, yaitu Penganten Cilik. Namun untuk kalangan orangorang yang penuh dengan harta, perayaannya akan sangat berbeda karena acaranya jauh lebih meriah. Tidak hanya penuh dengan pawai budaya dan arak-arakan massa yang umumnya menggunakan Grudaan, namun juga dengan pelbagai kelebihan lainnya. Lihat Rokmin Dahuri dkk., Budaya Bahari, 2004: 211-217.
} 
untuk mengatakan hal yang sama dengan anggapan awal. Idealisasi kehidupan masyarakat Cirebon tampaknya begitu jelas tertuang dalam WBG, dan idealisasi itu bisa berupa pernikahan yang cukup ilmu atau cukup harta. Walapun yang kemudian dilaksanakan oleh Bujang Genjong adalah cukup ilmu yang terefleksi ke dalam kerinduan untuk mencapai ma'rifatullah dengan cara manunggal diutamakan dengan menunda perkawinan yang dpat membahagiakannya dalam kehidupan dunia ini. Lebih mementingkan kebahagiaan yang kekal dan hakiki yang tak dapat direnggut oleh usia dan kematian. Usia dan kematian justru menjadi jembatan yang dapat mengantar kerinduan kepada Yang Abadi menjadi terbukti nyata dan terlaksana, tanpa tirai dan dinding, begitu lepas dan bebas, dan begitu nikmat dan lezat, bahkan tak terkira. Karena yang hakiki adalah sesuatu yang tak dapat digambarkan dan dilukiskan dengan kalimat dan tulisan. Segala kehendaknya terturuti tanpa ada larangan dan pantangan yang dapat menghancurkan atau membahayakannya. Kehidupan yang abadi tak punya batasan apapun untuk siapa pun. Mereka punya hak yang sama untuk merasakan sesuatu sesuai dengan amal perbuatannya, taqorrub, saat di alam fana. Di sana, semua menuai pahala dan tambahan, ziyadah, secara penuh dan adil tanpa kurang sedikitpun. Keadilan yang dijalankan adalah sebenarnya, bukan retorika belaka.

Model penafsiran dan penerjemahan WBG juga terbilang unik karena adanya dominasi dialog antar sesama jenis kelamin di dalam (yaitu antara lelaki dengan perempuan, lelaki dengan lelaki, dan perempuan dengan perempuan) yang bebas, sementara isi dialognya mengarah kepada nilai yang luhung dan agung. Tentang kesopanan bertutur kata, berprilaku, dan berilmu,sare'at, tarekat, hakekat, dan ma'rifat. Dan, dari pertengahan hingga akhir, dipenuhi dengan dialog tentang manunggal dalam versi mereka sendiri, atau manunggal versi Cirebon. Sementara kita belum punya rujukan yang dapat menjelaskan secara detail apa sebenarnya manunggal versi Cirebon dan terpengaruh dari mana, atau memang berdiri sendiri dengan filsafat yang mandiri pula.

Penerjemahan yang dilakukan pun sebenarnya belum sempurna. Kendala yang paling umum dalam masalah ini ketika menghadpai ungkapan yang kental sarat makna. Beberapa kali dicoba untuk melakukan perbaikan terhadap terjemahan-terjemahan yang sudah 
dikerjakan, akan tetapi hasilnya tetap masih kurang. Tidak sempurnanya penerjemahan ini disebabkan terpisahnya pemahaman yang timbul dari terjemahan yang ada. Seringkali terjemahan dari ungkapan-ungkapan, terkadang bahasa, tak dapat mengenai maksud yang dituju oleh naskah dengan bahasa aslinya. Perasaan kurang menyeluruhnya pemahamaman yang diperoleh oleh terjemahan sangat mendominasi.

Upaya untuk mempermudah proses transliterasi penerjemahan ini dilakukan dengan cara menambahkan nomor urut bait, dan huruf baris. Hal ini dilakukan agar pembaca dengan cepat melakukan pencocokan antara tejemahan dengan transliterasi atau bunyi naskahnya. Dengan begitu kesalahan-kesalahan yang ada dalam penerjemahan ini dapat segera diketahui untuk segera dilakukan perbaikan-perbaikan.

Meskipun di bumi Cirebon yang namanya naskah itu amat melimpah dan bertebaran dimanamana, nyatanya belum ada usaha penerjemahan dan penafsiran ajaran suluk yang langsung benar-benar mengacu pada naskah aslinya. Atau pendek kata, naskah-naskah suluk Cirebon belum ada yang diberi tafsiran secara penuh, dengan metode tekstual dan kontekstual, dengan metode tersirat dan tersurat, atau metode penulisan yang lain, sehingga menyulitkan bagi para filolog dalam memulainya. Andaipun demikian, memang sudah ada suluk Cirebon yang sudah diterjemahkan ke dalam bahasa Indonesia, tetapi belum sempat diberi tafsiran. Dan sayangnya penerjemahan itu sendiri tidak menyebutkan judul naskah aslinya, apalagi menyertakan transliterasi aksara atau hasil alih aksara dari bunyi naskah aslinya. Jika memang naskah aslinya tanpa judul dan pengarang, sebaiknya melampirkan hasil alih aksara di akhir buku sebagai bahan koreksi untuk suatu kesalahan yang mungkin timbul dari suatu penerjemahan.

Oleh sebab itu, upaya mengungkap kandungan WBG pun dilakukan dengan sangat serius. Segala kemampuan dan pengetahuan yang dimiliki tentang aturan dan tehnik penerjemahan dan penafsiran dari segala macam tembang seperi; kidung, tembang, puisi, sloka, wangsalan, sajak, dan bahkan kami pelajari juga tembang-tembang Arab dalam bentuk kosidah, nasyid, si'ir, dan nadham, mutlak dipelajari. Di samping itu, melakukan kajian komparatif atau perbandingan atas karakter bahasa, yang digunakan oleh WBG dengan karakter yang lain. Dari sana, tujuan yang mungkin dimaksud oleh penulisnya itu 
direnungkan dan dicari keseluruhan kontekstualnya. Berangkat dari situlah, akhirnya WBG dapat diterjemahkan dan ditasfsirkan dengan melihat, mempertimbangkan teks dan konteksnya.

\section{Menurut pengamatan yang amat seksama terhadap teks,} tembang yang ada di dalam WBG ini memiliki kemiripan dengan tembang-tembang tradisional lain, yang tersebar di berbagai pustaka dengan macam-macam bahasa dan bentuknya, terutama dalam hal pembukaanya dari segi penggunaan bahasa simbol, figur, dan tamsil antara naskah tua tersebut dengan tembang al Busyairi yang terkenal dengan nama Kosidah al Burdah (KB). Secara umum, WBG dan KB mempunyai perbedaan yang mendasar dan fundamental. Bagi $\mathrm{KB}$, bahasa Arab dan dengan kosidah sebagai bentuk tembangnya, menjadikan $\mathrm{KB}$ spontanitas diklaim sebagai karya sastera Arab yang langsung membuktikan ke-islaman orang yang menulisnya. Karena KB, di samping berisis pujian dan sanjungan kepada Rasulullah SAW, juga Tuhan yang wajib disembah disebut sebagai Allah SWT., dan KB membawa kita ke kedalaman cinta terhadap Allah SWT dengan perantaraan Rosul-Nya. Sementara WBG dengan bahasa Cirebon sebagai media komunikasinya dan tembang macapat sebagai pengantarnya, menjadikan WBG tak langsung dianggap sebagai karya Islami dan apalagi sebagai naskah yang berisi ajaran suluk (tasawwuf) yang penuh dengan ajaran cinta kasih, kerinduan, dan harapan kepada Allah SWT. WBG menyebut Allah SWT sebagai Dzat yang wajib disembah dan dicintai dengan sebutan Yang Agung, Yang Misesa, atau sebutan yang berbau Hindu yang lain. Dan diawal tembangnya sendiri, WBG tidak menyebut bismillah sebagaimana naskahnaskah keagamaan yang lain, atau bahkan naskah macapat yang lain. Namun demikian, perbedaan keduannya terletak pada kulit dan wadahnya saja. Ibarat wadah, WBG bisa diumpamakan dengan gelas, dan $\mathrm{KB}$ diumpamakan dengan dengan kendi, keduanya sama-sama berisi air cinta yang dapat memabukkan orang yang meminumnya dengan penuh rasa dahaga. Ibarat pakaian, WBG adalah kaos, dan KB adalah kemeja, keduanya sama-sama membungkus satu raga abadi yang hidup sepanjang zaman. Karena cinta tak akan pernah sirna dari dunia hingga manusia melebur dirinya dalam kehancuran lama semesta. Akan tetapi, hakikatnya, cinta akan bangkit lagi di alam keabadian akhirat seiring dengan pulihnya kesadaran ruh. Jika ruh telah 
mendapatkan kesadarannya kembali, setelah dibangkitkan, ruh akan kembali berenang dalam lautan kerinduan cinta yang pernah menenggelamkannya sewaktu di dunia fana. Kerinduan ruh pada Allah SWT bisa kita pahami dari kisah mahsyar yang diriwayatkan dalam hadis-hadis. Keduanya, baik KB maupun WBG, membawa kita ke kesadaran yang sama; bahwa Allah SWT adalah satu-satunya tujuan harapan bagi seluruh makhluk-Nya, dan akhir semua perjalanan (baca: suluk) yang dilakukan oleh para hambanya yang bertebaran di seluruh dunia dan menggunakan jalan dan metode yang berbeda. Allah SWT sebagai pencipta yang mampu memaksa seluruh hamba-Nya datang dan tunduk di hadirat-Nya, sekarang juga atau esok kelak.

Bagaimana, kapan, dan mengapa WBG ini disusun adalah diluar jangkauan kami, dan pemahaman kami tentang naskah tersebut secara tekstual maupun kontekstual tak sanggup menguraikannya. Akan tetapi, yang kami yakini adalah bahwa WBG memang benar sebagai naskah asli suluk pesisiran Cirebon yang memuat berbagai adat, tradisi, nilai, ajaran, dan gagasan yang dapat menjadi pedoman semua orang dan dapat dipertanggung jawabkan. Siapa yang menulis, hingga saat ini kami belum menemukan nama penulisnya. Selama penelusuran yang kami lakukan bersama tim, dengan cara perbandingan naskah, bertanya ke pemilik saat ini, dan dengan mencarai berita dari luar, kami belum menemukan nama penulis yang telah menyusun WBG ini. Memang dari banyaknya karya seni yang ada di Cirebon, khususnya seni sastra yang berhubungan dengan penulisan naskah, kita sering berhadapan dengan penulis yang misterius. Kebanyakan naskahnaskah Cirebon yang sempat ditemukan dan dapat dibaca adalah tanpa penulis (atau paling tidak penyalin) dan tanpa pengarang atau penyusun. Suasana anonymous seakan menghantui hampir semua (kebanyakan) naskah Cirebon yang ada sekarang, terutama yang ada ditangan kami (Pusat Koservasi dan Pemanfaatan Naskah Klasik Cirebon). Tapi kami yakin, haqul yaqin, bahwa keadaan ini bukan merupakan suatu unsur rekayasa dari orang-orang tertentu terhadap suatu naskah tertentu. Kami memahami, tradisi penulisan, bahasa yang digunakan, dan keadaan fisik naskah, dan digabungkan dengan kebiasaan penulisan orang zaman sekarang, naskah ini bukanlah hasil dari rekayasa yang disusun secara 
sistematis sehingga sulit di cari jejak kebohongannya.

Ada anggapan dan mungkin juga keyakinan yang mengatakan bahwa kesusasteraan Cirebon terpengaruh oleh sastera Jawa, Sunda, Arab, dan Melayu. Setelah kami meneliti satu demi satu kata yang tertulis dalam WBG, ternyata anggapan itu memang benar kenyataannya. Naskah yang berisi ajaran tasawuf ini membaur berbagai bahasa dengan kondisi yang mendukung isinya, sehingga tampak sahut-menyahut dan sambungmenyambung yang menjalin hubungan bahasa Jawa dan Sunda menuju ke pelaminan makna. Sehingga titik fokus pembicaraan makna, tujuan, dan ajaran dilebur kedalam dua kekayaan bahasa yang semakin enak untuk didengar dan ditembangkan. Tampaknya, penyusun WBG ingin menggayung setetes air makna di lautan sastera dengan berbagai gayung bahasa yang berbeda model dan bentuknya.

WBG harus mendapat perhatian dari kalangan yang sangat luas, tidak mesti sastrawan, budayawan, seniman, dan agamawan saja, melainkan hampir seluruh lapisan masyarakat. Pelbagai peneliti dengan sejumlah latar belakang yang berbeda pun diharapkan bisa mengisi kekosongan perspektif yang ada dalam kajian terhadap naskah yang unik ini. Begitu pula apabila ada seseorang yang mempunyai naskah WBG dengan versi lain atau lanjutan dari naskah ini dan ingin melakukan penerjemahan dan penafsiran secara mandiri, kami persilahkan untuk mengerjakannya. Dengan besar hati penuh kegembiraan, kami sambut usaha tersebut sebagai pelengkap dan penyempurna bagi usaha ini. Jika ada perbedaan isi naskah dari apa yang telah kami kerjakan, sebagian atau seluruhnya, maka kami anggap itu sebagai hal yang wajar dan biasa. Naskah versi Rumah Budaya Pasambangan Jati yang kami pegang pun tidak harus sama dengan apa yang mungkin ada ditangan pembaca, begitupun sebaliknya. Karena ini bukan kitab suci yang ditanggung pemeliharaan dan keabsahaanya oleh Allah SWT dan agama. Bagaimanapun, WBG adalah hasil karya orang tua kita yang mungkin sudah mengalami penyalinan beberapa kali dengan segala kekurangan dan kelebihannya. Penyalinan yang berarti penggandaan (reproduksi naskah secara manual) kadang terjadi penambahan atau pengurangan di dalamnya.

\section{E. Penutup}

Keindahan alam dan pemandangan yang menyejukkan 
merupakan ciri khas geografis Cirebon. Di sebelah utara Cirebon adalah Laut Jawa yang ombaknya cenderung tenang. Disebelah selatan, tampak Gunung Ciremai yang menawarkan panorama bebukitan yang kuat, teguh, diam, dan kokoh. Laut Jawa yang luas (menurut pandangan mata) memberi inspirasi kepada orang Cirebon agar lapang dada dan menerima segala bentuk budaya, aliran, dan paham. Dari Gunung Ciremai, orang Cirebon mengambil pelajaran tentang kekuatan tekad dengan penuh ketenangan jiwa. Dari sanalah muncul pribahasa Cirebon yang sering disampaikan oleh orang tua kita dahulu yang berbunyi; "amba segara masih amba atiningsun, gede gunung masih gede atiningsun" (luasnya lautan masih luas hati saya, besarnya gunung masih besar hati saya). Pribahasa ini, menjadi suatu ungkapan yang telah membesarkan dan melapangkan hati orang Cirebon berabad-abad.

Peribahasa tersebut menunjukkan bahwa orang Cirebon sejak dahulu telah memberikan warna pemikiran dan pangaruh tersendiri dalam tindakan sehari-hari masyarakat Cirebon sekarang. Pola pikir orang Cirebon dahulu yang cenderung menggambarkan dan menjelaskan pemahaman ajaran dengan metode tasybih dan tamsil, penyerupaan dan perumpamaan, menjadi tradisi turun-temurun dan terpelihara hingga tertuang dalam naskah-naskahnya, bahkan hingga sekarang. Wahosan Bujang Genjong (WBG) adalah salah satu contoh model pengajaran orang tua dahulu dengan menggunakan metode perumpamaan dan simbol-simbol.

WBG merupakan naskah model tembang (puisi) macapat ini menceritakan tentang dua sejoli yang saling jatuh cinta; si Pemuda bernama Bujang Genjong dan si Pemudi bernama Lara Gonjeng. Saat Bujang Genjong mengajukan lamaran kepada Lara Gonjeng, Lara Gonjeng menerimanya dengan satu syarat, yaitu Bujang Genjong harus tahu ilmu sejati. Pengajuan syarat seorang wanita, Rara Gonjeng, sebelum dinikahi oleh calon suaminya, Bujang Genjong, menjadi budaya yang klasik dan menjadi tantangan bagi calon mempelai pria. Budaya ini, dari sisi calon isteri, dapat mengambil kesimpulan tentang kapasitas dan kesungguhan calon suaminya. Dan dari sisi calon suami, membentuk kesanggupan dan ketabahan terhadap cara dan tahapan yang harus dijalani dan diperjuangkan.

Apabila melihat bentuk isinya, maka secara spontan kita pasti akan mengatakan bahwa WBG bukanlah 
suatu naskah yang secara khusus menjelaskan tentang suatu ajaran dan tuntunan tertentu. Tetapi bila kita cermati secara seksama dan hati-hati, WBG ternyata hendak mengajarkan kepada pembaca tentang sesuatu yang penting. Intinya, banyak orang sukses yang bertolak dari ceritacerita yang dia dengar dan dia idolakan dalam hidup dan sikap kerjanya. Hal inilah yang memberikan semangat kepada orang tua kita zaman dahulu yang selalu bercerita dan mendongeng untuk menghantar tidur anak-anaknya. Hal yang sama pula yang menyebabkan penulis WBG mengambil kisah cinta yang pasti romantis dalam petuah dan hikmah yang hendak disampaikan.

Petualangan Bujang Genjong dalam memenuhi syarat yang diajukan Rara Gonjeng, ternyata tidak berjalan secara standar ataupun monoton, melainkan terungkap adanya kehidupan masa remaja yang penuh semangat. Semangat untuk mendapatkan sesuatu yang menjadi kesenangan dan kebanggaannya. Dan pertarungan Bujang Genjong dalam pencarian ilmu manunggal lebih kepada gambaran atas resiko dan tanggungjawab yang harus di pikul oleh setiap orang untuk mendapatkan kebahagiaannya. Tanpa tantangan dan cobaan, hidup menjadi datar dan tidak berkembang ke arah yang lebih baik dan mulia. Seperti sekolah yang belum pernah menyelenggarakan ujian terhadap muridnya, dipastikan belum ada seorang murid pun yang pantas mendapat gelar kelulusan yang baik dan mulia. Inilah hidup, sealu beriringan dengan ujian dan cobaan. Hal itu pula yang di lakukan oleh Bujang Genjong demi mendapatkan cinta sejati dari Sang Rara Gonjeng.

\section{Daftar Pustaka}

Al-Ghazali, Abu Hamid Muhammad. 1989. Ihya 'Ulum al-Din. Beirut: Daar al Fikr. Juz III.

Arps, Ben. 1992. Tembang in Two Traditions: Performance and Interpretation of Javanese Literature. London: School of Oriental and African Studies.

Bahri, Saeful, dkk.. 2013. Koleksi dan Katalogisasi: Naskah Klasik Keagamaan Bidang Tasawuf. Jakarta: Balai Penelitian dan Pengembangan Agama Jakarta.

Bakhtiar, Amsal. 2003. Tasawuf dan Gerakan Tarekat. Bandung: Angkasa, 2003.

Dahuri, Rokhmin dkk. 2004. Budaya Bahari Sebuah Apresiasi di Cirebon. Jakarta: Perum Percetakan Negara Republik Indonesia. 
Irianto, Bambang dan Sutarahardja, Tarka. 2013. Sejarah Cirebon: Naskah Keraton Kacirebonan (Alih Aksara dan Bahasa Teks KCR 04). Muhamad Mukhtar Zaedin dan Panji Darussalam (Eds.). Yogyakarta: Deepublish.

Purwadi. 2005. Manunggaling Kawula Gusti: Ilmu Tingkat Tinggi untuk Memperoleh Derajat Kasampurnan. (Yogyakarta: Gelombang Pasang, 2005).

Pusat Penelitian dan Pengembangan Lektur Agama (Indonesia).
2005. Naskah Klasik

Keagamaan Nusantara:

Cerminan Budaya Bangsa, Vol.

I. Jakarta: Departemen Agama RI, Badan Litbang Agama dan Diklat Keagamaan, Puslitbang Lektur Keagamaan.

Supriatna, Yatna. 2008. Sastra Klasik Cerbon. Cirebon: Dinas Kebudayaan dan Pariwisata Kota Cirebon.

Tendi, "Islam dan Agama Lokal dalam Arus Perubahan Sosial", AtTahrir, Vol. 16, No. 1 (2016). 